\title{
Contents
}

90

On Editing Elizabethan Plays

CYRUS HOY

100

The Double Gift: Inner Vision and Pictorial Sense in Petrarch

ELIO GIANTURCO

112

Milton Edits Freigius' "Life of Ramus"

LEO MILLER

115

BOOK REVIEWS

\section{CHARLES TRINKAUS}

J. G. Rowe and W. H. Stockdale, eds. FLORILEGIUM HIS TORIALE

W. STANFORD REID

Sixteenth Century Essays and Studies, edited by Carl S. Meyer

W. H. DRAY

George Huppert. The Idea of Perfect History

MARION E. BROWN

Albert Fidelis Butsch. Handbook of Renaissance Ornament

DAVID SINCLAIR

Peter G. Bietenholz. Basle and France in the Sixteenth Century

ERMINIO G. NEGLIA

Louis B. Wright. Gold, Glory and the Gospel

JUAN BAUTISTA AVALLE-ARCE

Rachel Bromberg. Three Pastoral Novels

PETER N. DUNN

Otis H. Green. The Literary Mind of Medieval and Renaissance Spain

WALTER TEMELINI

Nancy S. Struever. The Language of History in the Renaissance

JOSEPH G. FUCILLA

Short-Title Catalog of Books Printed in Italy and of Books in Italy and of Books in Italian Printed Abroad 1501-1600.

WILLIAM SHEA

Jèrome J. Langford. Galileo, Science and the Church

OLGA Z. PUGLIESE

Robert S. Lopez. The Three Ages of the Italian Renaissance

MICHAEL UKAS

Robert J. Rodini. Antonfrancesco Grazini, Poet, Dramatist, and Novelliere ROBERT N. SHERVILL

Raymond R. MacCurdy, ed. Spanish Drama of the Golden Age

JOHN W. ABRAMS

Antoinette Mann Paterson. The Infinite Worlds of Giordano Bruno

NEWS

Renaissance and Reformation VOLUME VIII 1972 NUMBER 3 